\title{
学界情報
}

\section{International Conference on Smart Grids and Energy Systems （SGES2020）報告}

山口遼〔中部電力(株)]

\section{1. はじめに}

SGES 2020 がオンライン形式にて 2020 年 11 月 23 日〜 26 日に開催された。本大会はスマートグリッド関連技術の 国際会議であり，新型コロナウイルスの影響でオーストラ リアのパース（図 1）にて開催予定であった International Innovative Smart Grid Technologies Conference - Asia （ISGT-ASIA）2020 が中止となったため，それを引き継ぐ形 で開催された。

\section{2. 大会概要}

SGES 2020 では，12 件のキーノートトーク，5 件のチュ 一トリアルセッション，1件のインダストリーフォーラム， および表 1 に示すセッション分類による 180 件の論文発表 が行われた。本大会では日本の投稿論文は 33 件であり，国 別では, 中国, オーストラリアに次いで 3 番目に多い件数 であった。

論文発表のうち 10 セッションが電力・再生可能エネルギ 一工学に属する一般セッション，その他 4 件はスマートグ リッド関連分野の特別セッションであった。一般セッショ ンは, 需給予測, 系統運用・計画, 系統レジリエンス・系

表 1 セッション分類と論文件数

\begin{tabular}{|c|c|c|}
\hline No & セッション & 件数 \\
\hline 1 & $\begin{array}{l}\text { Energy Forecasting, Peer-to-peer Energy Trading } \\
\text { and Transactive Energy Management }\end{array}$ & 8 \\
\hline 2 & Grid Planning, Operation and Management & 24 \\
\hline 3 & Grid Resiliency, Reliability, Stability and Protection & 16 \\
\hline 4 & $\begin{array}{l}\text { Microgrids, Standalone Power Systems and Virtual } \\
\text { Powers Plants }\end{array}$ & 24 \\
\hline 5 & Power and Energy Systems & 7 \\
\hline 6 & $\begin{array}{l}\text { Renewable Generation and Distributed Energy } \\
\text { Resources }\end{array}$ & 24 \\
\hline 7 & Smart Grids and Active Distribution Networks & 8 \\
\hline 8 & $\begin{array}{l}\text { Smart Homes, Buildings and Cities and Cyber } \\
\text { Security }\end{array}$ & 8 \\
\hline 9 & $\begin{array}{l}\text { Smart Homes, Buildings and Cities and Emerging } \\
\text { Technologies and End-user Systems }\end{array}$ & 7 \\
\hline 10 & Smart Power and Energy Systems & 23 \\
\hline $\begin{array}{ll}11 \\
※\end{array}$ & $\begin{array}{l}\text { Advanced Machine Learning, Data Mining and } \\
\text { Optimization Technologies in Power and Energy }\end{array}$ & 8 \\
\hline 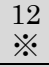 & $\begin{array}{l}\text { Advanced Operation, Control and Data Analytics } \\
\text { for Energy Storage Systems in Smart }\end{array}$ & 7 \\
\hline $\begin{array}{l}13 \\
※\end{array}$ & Electricity Market Design, Modeling and Simulation & 8 \\
\hline $\begin{array}{l}14 \\
※ \\
\end{array}$ & $\begin{array}{l}\text { Robust and Reliable Operation of Highly PV } \\
\text { Penetrated Active Distribution Networks }\end{array}$ & 8 \\
\hline
\end{tabular}
※ : No11〜No14 は特別セッション

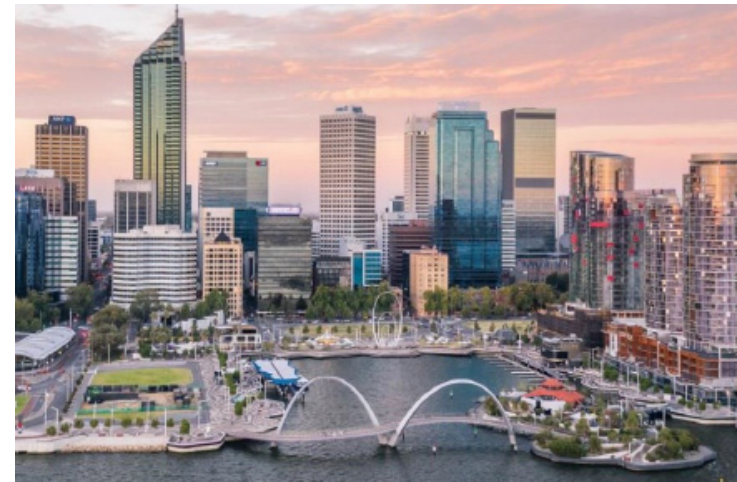

困 1 オーストラリアパース

SGES2020 HP (URL: https://www.sges2020.org/)

統信頼度・系統安定度, マイクログリッド・バーチャルパ ワープラント $(\mathrm{VPP})$, 再生可能エネルギー・分散電源, ス マートグリッド，スマートホーム，エネルギーマネジメン 卜等に大別される。また, 特別セッションでは, 機械学習・ データマイニング・最適化技術, データ活用による系統運 用の高度化, 電力市場, 配電系統の高信頼度な運用手法等 に関する発表が行われた。

これら口頭発表は 3 セッションが並行して行われた。発 表時間は論文 1 件につき 12 分であり，発表 1 件あたり 2 4 件程度の質問・コメントがなされた。また, 特に優秀であ った 6 件の学生論文には Best Student Paper Award が授与 された。

キーノートトーク及びチュートリアルセッションでは, スマートグリッドを形成する電気自動車・蓄電池・インバ 一タ機器に関する最新技術の紹介や，それら技術を活用す るための電力系統形成・電力市場設計の国際動向に関する 講演が行われた。また, インダストリーフォーラムでは電 力系統のレジリエンス強化に必要な取り組みについて活発 な議論がなされた。

閉会式には多くの人が参加し, Best Student Paper Award の授与と，バーチャルでの集合写真撮影が行われた。

\section{3. あとがき}

全てのセッション・イベントがオンラインでの開催でし たが，SGES2020 は活気ある素晴らしい大会となりました。 新型コロナウイルスの影響で社会情勢が大きく変化する厳 しい状況の中, 大会の開催に尽力された関係者の皆様に深 く感謝の意を示します。

次回の ISGT-ASIA は 2021 年 12 月 5 日〜 12 月 8 日に オーストラリアのブリスベンで開催される予定です。

(2021 年 4 月 6 日受付) 